\title{
A COMPARATIVE STUDY BETWEEN SOME PREDATORY MITE SPECIES OF PHYTOSEIID MITES TO DETERMINE ITS ABILITY TO SURVIVE WITH OR WITHOUT WATER Abdallah, A. A. ${ }^{1}$ and H.M.G. El-Kawas ${ }^{2}$ \\ 1 Agric. Zoology and Nematology Dept. Fac. Agric., Al - Azhar Univ. 2 Plant Protection Res. Inst., Agric. Res. Centre, Dokki, Egypt
}

\begin{abstract}
The three different life styles phytoseiid predatory mite species, Phytoseiulus macropilis (Banks), Amblyseius californicus (McGregor) and A. cucumeris (Oudemans) were observed to investigate their ability to survive without food, young females were caged individually in the absence of prey, either with or without water.

In general, the female survival time with water was four to six and half times as long as the survival times without water regardless of the species. In the survival experiment without water, $P$. macropilis and $A$. cucumeris both lived shorter than $A$. californicus. In the survival experiment with water, $A$. californicus lived nearly 2 times longer than P. macropilis or A. cucumeris. Amblyseius californicus females showed a strong capacity to survive without food, which could be an important factor contributing to the persistence of $A$. californicus in comparison to other phytoseiids.
\end{abstract}

Keywords: Phytoseiulus macropilis, Amblyseius californicus and A. cucumeris

\section{INTRODUCTION}

The phytoseiid mites are important biological control agents of pest mites in orchards, citrus crops, grapes and glasshouses (Helle and Sabelis, 1985), and they are effective in controlling tetranychids in a variety of situations, most notably in greenhouses (Dixon, 1973). Phytoseiid mites are the best-known predators among the Acari and may easily be mass-reared and shipped (Overmeer, 1985). They are small mesostigmatic acarines (200$500 \mu \mathrm{m}$ in length) (Chant and McMurtry, 1994).

Predator persistence after prey extinction is often related to its capacity to survive on a variety of foods and to compete successfully with other predatory species, frequently of closely related taxa (Duso and Vettorazzo, 1999). Phytoseiid mite species could differ in life style, feeding habits, dispersal ability and levels of persistence in absence of prey pest, this may that affect their efficiency and performance as potential biocontrol agents (Abdallah, 2002). McMurtry and Croft (1997) suggested that four different lifestyles have evolved in phytoseiid mites, based primarily on differences in food utilisation. The current study was conducted using three predatory mite species, one from each lifestyles: Phytoseiulus macropilis (type I), a specialised predator of species of genus Tetranychus; Amblyseius californicus (type II), a selective predator of tetranychid mites that often associate with spider mites that produce dense webbing; $A$. cucumeris (type III) which is generalist predator feeding on various mites, insect species and pollen. Phytoseiulus macropilis (Banks) is the most common phytodeiid predator of spider mites (Saba, 1974; Amin el al., 2009). Amblyseius 
californicus (McGregor) has a worldwide distribution, but favours semiarid and Mediterranean climates (McMurtry, 1977). This species is widely used in integrated pest management programmes for the biological control of tetranychid mites (e.g. Oatman et al., 1977; Pickett and Gilstrap, 1986; Jolly, 2000; Easterbrook et al., 2001). Amblyseius cucumeris (Oudemans) could effectively feed on thrips and whitefly larvae, spider mites and pollen (Sabelis and Van Rijin 1997; Arthurs et al., 2009). This species is widely used for biological control of thrips in greenhouses (Sabelis and Van Rijin 1997).

The aim of the present work threw light on young female of the three predatory mite species which were kept singly in cages, with or without water, to investigate their survival ability without food and to estimate possible survival time of the species after prey extinction. The experiments were carried out at $25 \pm 1^{\circ} \mathrm{C}$ with a $16 \mathrm{~L}: 8 \mathrm{D}$ photoperiod and $60 \pm 15 \% \mathrm{RH}$.

\section{MATERIALS AND METHODS}

\section{Rearing of mite species:}

Predatory mite species were reared on two-spotted spider mite $T$. urticae. Amblyseius californicus and $P$. macropilis were reared using methods modified from (McMurtry and Scriven, 1965), large plastic boxes $26 \times 15 \times 10$ $\mathrm{cm}$. were used, cotton pad were placed in the middle of each box, leaving a space provided with water as a barrier to prevent predatory mites from escaping. Excised bean leaves highly infested with spider mite, Tetranychus urticae Koch, were provided every day as food source for mites. As Amblyseius cucumeris avoids webbed leaves, it was cultured here by a slightly different method involving spider mites only. Heavily infested bean leaves with spider mites were placed on a $19 \times 19 \mathrm{~cm}$ black plastic sheet, which was placed on a filter paper $20 \times 20 \mathrm{~cm}$ resting on a similarly sized piece of absorbent cotton wool (2cm thick) in an open plastic pan $(23 \times 23 \times 5$ $\mathrm{cm})$. After few hours the leaves started to dry out and $T$. urticae started moving from the leaves onto the sheet, enabling the predator to consume them without being entangled in the webs on the leaves. This method led to the build up of a large colony of $A$. cucumeris on $T$. urticae. Water was added to the plastic pan whenever required, to prevent the mites from escaping. The culture units for all species were kept at room temperature $\left(25 \pm 3^{\circ} \mathrm{C}\right)$.

\section{Preparation of same age predators:}

To obtain a new generation of females of the same age, gravid females of $P$. macropilis and $A$. californicus were randomly selected from cultures (30 to 40 per species) and released onto detached bean leaves (one for every 10 females), heavily infested with $T$. urticae. The heavily infested bean leaves were placed up-side down on a filter paper $(9 \times 9 \mathrm{~cm})$, which was placed on a piece of cotton wool (approximately $9 \times 9 \times 1 \mathrm{~cm}$ ). The cotton wool was soaked with water in an experimental plastic box $(10 \times 10 \times 2 \mathrm{~cm})$. After 24 hours, the females were removed and the eggs laid by each species were kept until hatching. Leaves with the larval stage were then transferred to new culture rearing units. Leaves heavily infested with spider mites were added 
daily for these immature to ensure a good supply of food until three to four days after reaching adulthood. Gravid females were randomly selected for use in the experiment.

\section{Experimental design:}

Survival assessment of starved predators without water (Nil): For each predator species, 30 adult female were placed singly in closed cages with and without free available water. Each cage (Figure 1) consisted of a rectangular plexiglass $(8 \times 3.5 \times 0.5 \mathrm{~cm}$ with a $1.5 \mathrm{~cm}$ diameter hole drilled in the middle and covered by fine nylon mesh (mesh apertures $76 \mathrm{~mm} 2$ ) glued on one side. The other side of plexiglass was sealed by a glass slide placed above it. Glass slide and plexiglass were then held together by bulldog clops on both ends. A plastic box $(17 \times 11 \times 5 \mathrm{~cm})$ with its roof area subdivided into partitions using wire, held the assessment units down vertically.

Survival assessment of starved predators with water: The cages used in this experiment were as above except that a piece of damp filter paper with a hole corresponding to that in the plexiglass was placed between the slide and the plexiglass.

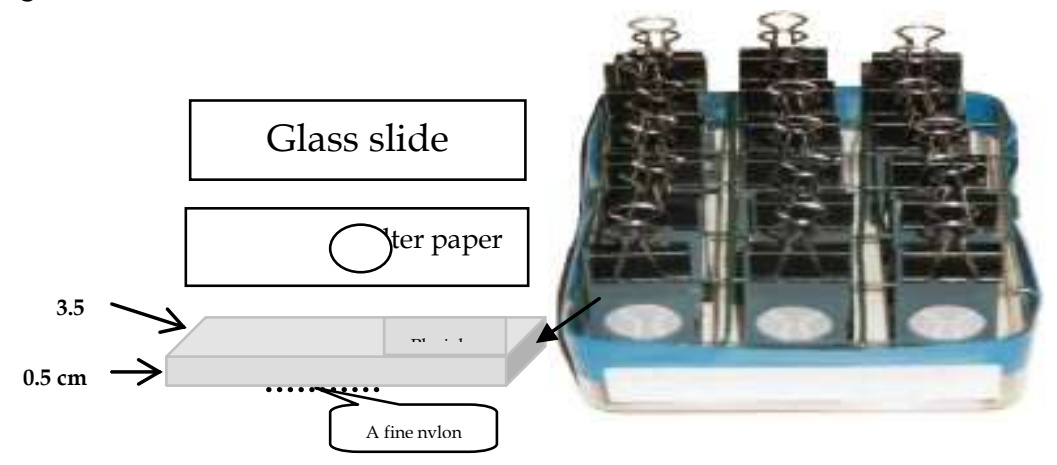

Figure 1: Photograph and schematic diagram for the experimental cages

The hole in the filter paper being necessary for observation of the mites during the experiment. The cages were placed upright with the filter paper in contact with a $1 \mathrm{~cm}$ thick layer of cotton wool filled with water on the floor of the plastic box. The filter paper strip could hence act as a wick to bring moisture to the mites. Water was added daily to the cotton wool as needed. The cages were arranged in a plastic base and held in place with wire as before (Figure 1).

\section{Experimental procedure:}

Thirty (assessment units) were prepared for each predatory species in each experiment 15 with and 15 without water and placed in plastic boxes as described previously in an incubator at $25 \pm 1{ }^{\circ} \mathrm{C}$ with a $16 \mathrm{~L}: 8 \mathrm{D}$ and $60 \pm 15 \%$ $\mathrm{RH}$.

\section{Data collection:}

The survival time of the three predatory mite species with and without water was observed under a binocular microscope (15X). For mites provided 
with water, observations were made every 12 hours until all predators died. For mites without water, observations were made every 6 hours on the first day and every 3 hours on the second and third day.

\section{Data analysis:}

One-way analysis of variance (ANOVA) and mean comparison using Fisher's least significant difference (LSD) were conducted for the survival time with or without water for the three predatory species, using super ANOVA program (Gagnon et al., 1989).

\section{RESULTS}

\section{Survival of predatory mite species with or without water:}

In general, the minimum survival in all cases with water was much greater than the maximum survival time without water $(P<0.001$; Table 1$)$.

There was a significant difference among the three predatory mite species in survival time without water $\left(F_{2,42}=31.45 ; P<0.001\right)$. Amblyseius californicus showed longer survival time $(55.60 \pm 7.07$ Hours $)$ than $P$. macropilis (LSD; $P<0.001$ ) or $A$. cucumeris (LSD; $P<0.001$; Table 1).

Likewise, there were significant differences among the three predatory mite species in survival time with water $\left(F_{2,42}=6.45 ; P<0.001\right)$. Amblyseius californicus showed longer survival time $(15.07 \pm 2.81$ days; $P<0.001)$ than $P$. macropilis (LSD; $P<0.001$ ) or $A$. cucumeris (LSD; $P<0.001$; Table 1).

As shown in Figure 2, survival of the three predatory mite species without water was $100 \%$ until 36 hours, then it decreased and by 51 hours, survival rates were $60 \%$ for $A$. californicus, $20 \%$ for $P$. macropilis and $40 \%$ for $A$. cucumeris. After that, survival rates of $A$. cucumeris and $P$. macropilis continued decreasing sharply to reach zero at 57 hours. The survival rate of A. californicus was still $40 \%$ when the other two species were extinct; after that the survival rate of $A$. californicus continued decreasing to extinction at $66 \mathrm{~h}$.

Table 1: Survival time for the three predatory mite species with or without water

\begin{tabular}{|l|c|c|c|c|c|c|}
\hline \multirow{3}{*}{ Species } & \multicolumn{5}{|c|}{ Survival time } \\
\cline { 2 - 7 } & \multicolumn{3}{|c|}{$\begin{array}{c}\text { Without water (Nil) } \\
\text { (Hours) }\end{array}$} & \multicolumn{3}{c|}{$\begin{array}{c}\text { With water } \\
\text { (Days) }\end{array}$} \\
\cline { 2 - 7 } & Mean \pm SD & Max. & Min. & Mean \pm SD & Max. & Min. \\
\hline A. californicus & $55.60 \pm 7.07_{\mathrm{a}}$ & 66.00 & 45.00 & $15.07 \pm 2.81_{\mathrm{a}}$ & 19.00 & 10.00 \\
\hline P. macropilis & $47.60 \pm 6.20_{\mathrm{b}}$ & 60.0 & 36.00 & $8.40 \pm 2.13_{\mathrm{b}}$ & 12.00 & 5.00 \\
\hline A. cucumeris & $50.00 \pm 5.40_{\mathrm{b}}$ & 57.00 & 39.00 & $8.60 \pm 2.85_{\mathrm{b}}$ & 13.00 & 5.00 \\
\hline
\end{tabular}

Means in column followed by different subscript letters within columns are significantly different from each other $(P<0.05)$ LSD test 


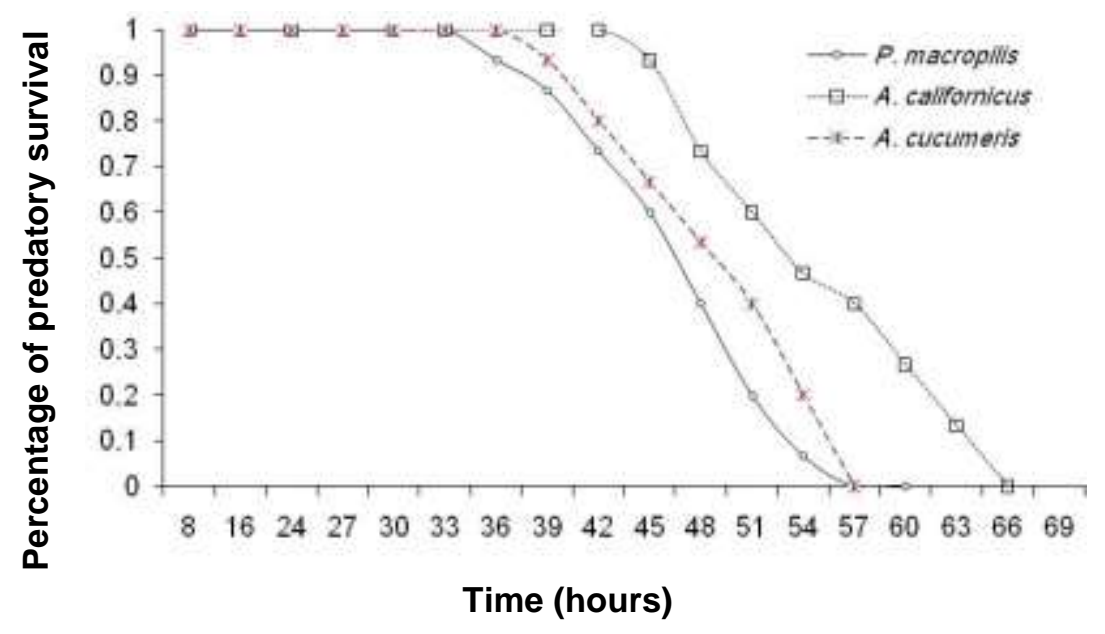

Figure 2: Percentage of survival time (Hour) for the three predatory mite species without water (Nil)

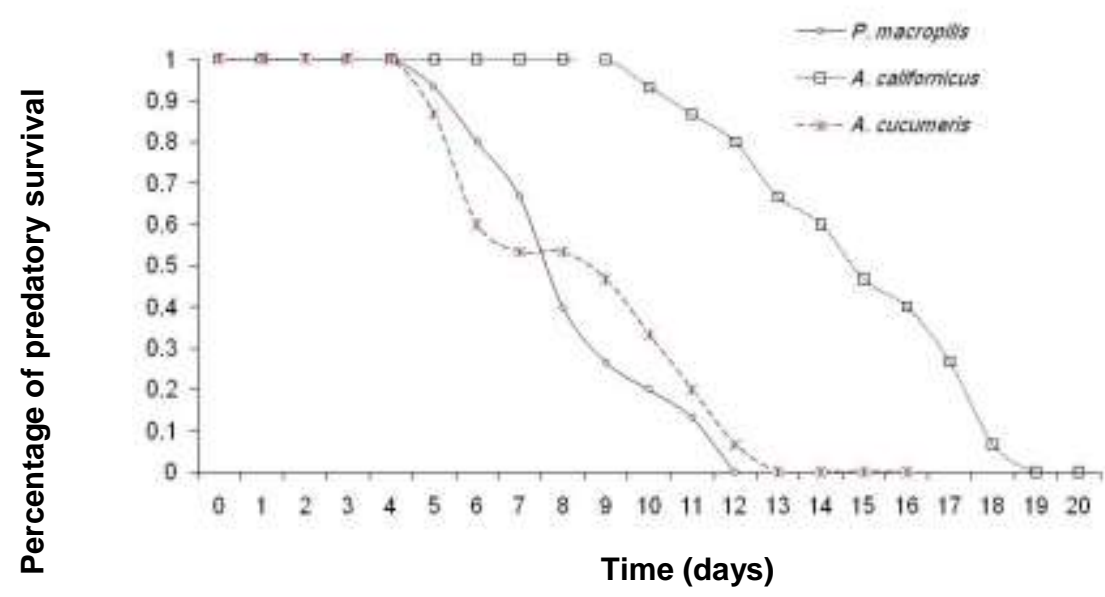

Figure 3: Percentage of survival time (Day) for the three predatory mite species with water

The survival of all species with water was $100 \%$ until day 4. Amblyseius cucumeris then decreased sharply until day 7 after that they started to decrease steadily on day 9 to extinction on day 13, while $P$. macropilis declined from $100 \%$ survival on day 5 to extinction on day 12. Amblyseius californicus continued at $100 \%$ survival until day 9 then decreased steadily to extinction on day 19. 


\section{DISCUSSION}

\section{Predatory mite species survival with or without water:}

The female survival time with water was more than four times as long as the survival times of the females without water. The survival times were more than four times longer for both species $A$. cucumeris and $P$. macropilis. The access to water had the greatest effect on $A$. californicus, females died within 2.50 days without water, while in the cages with access to water females survival form 10 to 19 days; more than six and half times longer. Amblyseius californicus, adults as well as immatures, apparently have lower food requirements and can survive longer without food than $P$. persimilis (Abdallah, 2002).

Female survival was short without water, but was increasingly longer with water. The water balance strategies of these differentially adapted mites are likely to differ. For example, the net water losses through the cuticle and from respiration for Typhlodromus occidentalis (Nesbitt) and Amblyseius finlandicus are balanced by drinking water from droplets or as vapour or in the form of spider mite blood (Yoder and Barcelona, 1995). Additional water is probably gained by probing leaf tissue (Porres et al., 1976).

This effect is strongest in $A$. californicus females, which could be an important factor contributing to the persistence of $A$. californicus in comparison to other phytoseiids. Predator persistence beyond prey extinction is important for biocontrol programmes as pockets of spider mite infections may persist.

\section{REFERENCES}

Abdallah, A.A. 2002. Potential of predatory phytoseiid mites to control phytophagous mites. Ph.D. Thesis, Imperial College, London Univ., UK, $237 \mathrm{pp}$.

Amin, M. M., Mizell R. F., and Flowers, R. W., 2009. Response of the predatory mite Phytoseiulus macropilis (Acari: Phytoseiidae) to pesticides and kairomones of three spider mite species (Acari: Tetranychidae), and non-prey food. Flo. Ent. 92(4): 554- 562.

Arthurs, S.; McKenzie, C L.; Chen, J.; Dogramaci, M.; Brennan, M.; Houben, K.and Osborne, L. 2009. Evaluation of Neoseiulus cucumeris and Amblyseius swirskii (Acari: Phytoseiidae) as biological control agents of chilli thrips, Scirtothrips dorsalis (Thysanoptera: Thripidae) on pepper. Biological Control 49: 91-96

Chant, D.A. and McMurtry, J.A. 1994. A review of the subfamilies Phytoseiinae and Typhlodrominae (Acari: Phytoseiidae). Int. J. Acarol. 20(4): 223-316.

Dixon, G.M. 1973. Observations on the use of Phytoseiulus persimilis AthiasHenriot to control Tetranychus urticae (Koch) on tomatoes. Plant Path. 22(3): 134-138. 
Duso, C. and Vettorazzo, E. 1999. Mite population dynamics on different grape varieties with or without phytoseiids released (Acari: Phytoseiidae). Exp. Appl. Acarol. 23: 741-763.

Easterbrook, M.A.; Fitzgerald, J.D. and Solomon, M.G. 2001. Biological control of strawberry tarsonemid mite Phytonemus pallidus and twospotted spider mite Tetranychus urticae on strawberry in the UK using species of Neoseiulus (Amblyseius) (Acari: Phytoseiidae). Exp. Appl. Acarol. 25: 25-36.

Gagnon, J.; Roth, J.M.; Carroll, M; Haycock, K.A.; Plamondon, J.; Feldman, D.S. and Simpsoon, J. 1989. Super ANOV accessible general linear modelling. Abacus Concepts, Berkeley, CA.

Helle, W. and Sabelis, M.W. 1985. World Crop pests: Spider mites, their biology, natural enemies and control, Vol: 1B. Elsevier, Amsterdam. $458 \mathrm{pp}$.

Jolly, R.L. 2000. The predatory mite Neoseiulus californicus: its potential as a biocontrol agent for the fruit tree red spider mite Panonychus ulmi in the UK. Proc. Brighton Crop Prot. Conf.: Pests and Diseases 1: 487490.

McMurtry, J.A. 1977. Some predaceous mites (Phytoseiidae) on citrus in the Mediterranean region. Entomophaga 22(1): 19-30.

McMurtry, J.A. and Croft, B.A. 1997. Life-styles of phytoseiid mites and their role in biological control. Ann. Rev. Ent. 42: 291-321.

McMurtry, J.A. and Scriven, G.T. 1965. Life-history studies of Amblyseius limonicus with comparative observations on Amblyseius hibisci (Acarina: Phytoseiidae). Ann. Ent. Soc. Am. 58: 106-111.

Oatman, E.R.; McMurtry, J.A.; Gilstrap, F.E. and Voth, V. 1977. Effect of releases of Amblyseius californicus on the two-spotted spider mite on strawberry in southern California. J. Econ. Ent. 70: 638-640.

Overmeer, W.P.J. 1985. Rearing and handling, pp. 161-170. In World Crop Pests: Spider mites, their biology, natural enemies and control, Helle, W. and Sabelis, M.W. (eds), Vol. 1B. Elsevier, Amsterdam

Pickett, C.H. and Gilstrap, F.E. 1986. Inoculative releases of phytoseiids (Acari) for the biological control of spider mites (Acari: Tetranychidae) in corn. Envir. Ent. 15(4): 790-794.

Porres, M.A.; McMurtry, J.A. and March, R.B. 1976. Investigations of leaf sap feeding by three species of phytoseiid mites by labelling with radioactive phosphoric acid (H3 32PO4). Ann. Ent. Soc. Am. 68(5): 871-873.

Saba, F. 1974. Life history and population dynamics of Tetranychus tumidus in Florida (Acarina: Tetranychidae). Flo. Ent. 57: 47-63.

Sabelis, M.W. and Van Rijin, P.C.J. 1997. Predation by insects and mites, pp. 259-354. In Thrips as crop pests, Lewis, T. (ed). CAB International, London.

Yoder, J.A. and Barcelona, J.C. 1995. Food and water resources used by the Madagascan hissing cockroach mite, Gromphadorholaelaps schaeferi. Exp. App. Acarol. 19: 259 - 273. 
دراسة مقارنة لبعض الانواع الأكاروسيه المفترسه على المعيشة بالماء أو بدونه

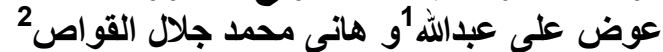

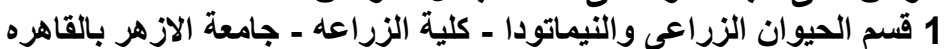

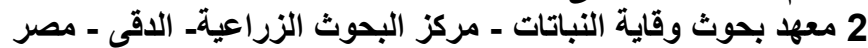

تم إختبار ثلاثة انو اع من انماط مختلفة من المفترس الفيتوسيدى النوع الـ Phytoseiulus

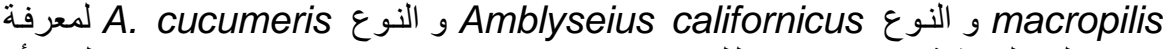

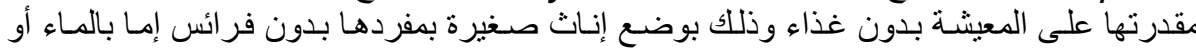

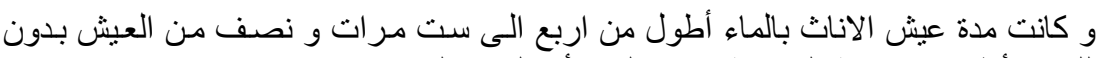
بدونه.

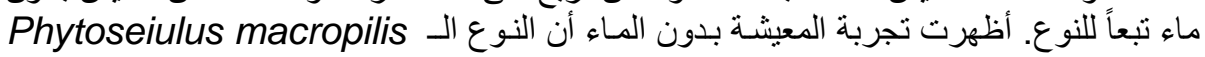

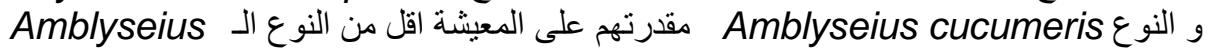

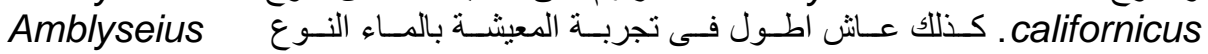
ما يقرب من مرتين من النوع الـ Californicus .Amblyseius cucumeris أظهرت اناث النوع الـ Amblyseius californicus مقدرتها القويـه على المعيثـة بدون غذاء و هذا يعتبر عامل هام يساعدها على استمر ارها مقارنة بالانو اع الاخرى.

كلية الزراعة - جامعة المنصورة

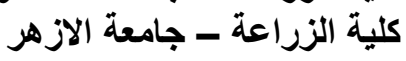

قام بتحكيم البحث

أ.د / أد / عمر عبد الحميد نصار

أ.د / أد / عدحت محمد احمد سيد نصيار 